\title{
Fazer uma escola. Da/UAL = To build a school. Da/UAL ${ }^{1}$
}

\author{
Madalena Romão Mira \\ mmira@autonoma.pt \\ Universidade Autónoma de Lisboa \\ Centro de Investigação em Ciências Históricas
}

Para citação: MIRA, Madalena Romão - Fazer uma escola. Da/UAL = To build a school. Da/UAL Estudo Prévio 16. Lisboa: CEACT/UAL - Centro de Estudos de Arquitetura, Cidade e Território da Universidade Autónoma de Lisboa, 2019. ISSN: 2182-4339 [Disponível em: www.estudoprevio.net]. DOI: https://doi.org/10.26619/2182-4339/16.01

Recensão recebida a 27 de novembro de 2019 e aceite para publicação a 2 de dezembro de 2019.

Creative Commons, licence CC BY-4.0: https://creativecommons.org/licenses/by/4.0/

Não me é fácil fazer uma recensão a um livro de entrevistas. A arquitetura apresentase-nos aqui como um palco cujo protagonista é o Departamento homónimo da Universidade Autónoma de Lisboa, com uma vida já de duas décadas e muitas conquistas, e muitas personagens excecionais com experiências ímpares.

O livro, como o mundo, divide-se em duas partes. Abre com uma cronologia, em linha reta, com um olhar que parte de hoje para o passado, numa conceção histórica que surge de uma forma que nos leva a percorrer, também, um círculo de 20 anos em direção à fundação da Escola, espelhando, na minha leitura (de uma simples leitora sem cultura arquitetónica) a conceção de arquitetura. Os sucessivos diretores da Escola contribuem com uma reflexão sobre o momento em que a lideraram, em percursos distintos, com andamentos que se assemelham a instrumentos musicais, portadores de diferença na mesma linha cenográfica da construção da Escola.

Contribuem para esta sensação as linhas retas, os círculos, os caleidoscópios de vidas entrevistadas, cada uma com uma textura distinta, todas intensas. Contribui

\footnotetext{
${ }^{1}$ A Estudo Prévio agradece à autora o convite para a elaboração deste texto, assinalando o lançamento do livro Fazer uma escola. $\mathrm{Da} / \mathrm{UAL}=$ To build a school. $\mathrm{Da} / \mathrm{UAL}$, resultante das entrevistas realizadas pela Estudo Prévio entre 2011 e 2017.
} 
para esta sensação, igualmente, ter o livro na mão, relembrar o seu conteúdo (já lá irei) e a forma como está feito: criou-se um ambiente, uma edificação cujo projeto foi pensado, e bem pensado. Sinto conforto, conhecimento e, confesso, uma vontade incrível de me inscrever, principalmente na disciplina de Desenho.

A segunda parte do livro é constituída por entrevistas a nomes que deixam cicatriz na arquitetura do mundo. A visualidade expressa na escrita e absorvida na leitura lembra um filme, com vários realizadores e histórias paralelas unidas por um denominador comum. Não, não como filme, mas antes como um documentário, cujos protagonistas se nos apresentam no ecrã, se expõem, se nos oferecem, virtude da entrevista, quando o entrevistado é bom, quando partilha sobre as suas opções, indecisões, avanços e recuos de pensamento, quando se mostra humano, sabendo que é sua a autoria de equipamentos que usamos diariamente, contribuidores para a arquitetura vivida do nosso mundo diário.

Ainda que falem de teoria, de investigação, da história da arquitetura, é num discurso muito visual, onde as viagens estão sempre presentes e dão uma dimensão transtemporal e transgeográfica à leitura, levando-nos dos exemplos clássicos às mais contemporâneas criações.

Não tenho, de todo, cultura arquitetónica, mas sinto-me fascinada pelo belo, pelo estranho ao olhar, pela novidade, pelo conforto, pelo simples, pelo seguro, pela qualidade, pela adaptação de sonhos a lugares de estar, ou de passagem, como as pontes, que nos fazem sonhar. Fazem-nos sentir bem. E parece coisa pouca, este sentir bem, mas não é.

As entrevistas partilham sentimentos (quase) unânimes sobre as Escolas de Lisboa e do Porto, respeito e admiração por professores que deixaram marcas de vida nos entrevistados, perpassam a necessidade de o arquiteto ser mais interventivo politicamente, apontam o bom casamento entre o estudo e o trabalho em atelier, sugerem inícios de carreira com projetos familiares ou de amigos, obrigam (no melhor dos sentidos!) a viajar, o que se complementa com um olhar global uníssono, a vários níveis, do qual se conclui que os olhos não podem ter intermediários. Excelente sugestão, que me trouxe de volta tanta viagem, lembrança, espantos de recordações que tinha guardadas, arrumadinhas, e que agora saltaram para a linha da frente da memória.

Àquelas linhas comuns acrescente-se o registo de subversão apontado por Manuel Graça Dias (1953 - 2019), a abertura de conceber a descoberta da arquitetura por parte dos alunos em diferentes momentos do curso, de José Adrião, a visão holística e transdisciplinar de Inês Lobo, a perspetiva da aprendizagem do nosso lugar no mundo, de Nuno Mateus, a persistência, passada aos alunos, da necessidade de ganhar liberdade e de a manter, de Manuel e Francisco Aires Mateus, a conjugação da riqueza que vem do passado com a riqueza que é o presente, de Ricardo Carvalho, o entendimento da cidade inteira como território de um edifício, de João Santa-Rita, a procura do impacto nas vidas das pessoas que se reflita também em retorno pessoal para o próprio arquiteto, de Pedro Reis, o olhar para as arquiteturas vernáculas do mundo e o reconhecimento de fios condutores de decisões que vão otimizando soluções, de Telmo Cruz, o tema, fortíssimo, da colaboração, transmitido por João Gomes da Silva, a tentativa de postura marítima, da captação das ondas boas para apanhar, que resulta da atenção a vivências aparentemente desconetadas 
PT | L02 | EP16| w2019

da arquitetura, de João Luís Carrilho da Graça, e a frontalidade sobre a questionável aprendizagem pelos livros, de Manuel Vicente (1934-2013) que, como eterna bibliotecária, deixei para o fim, contrariada em aceitar, mas a compreender o que diz no contexto em causa.

Todas estas visões contribuíram para fazer uma Escola, e não tenho a certeza se os alunos se apercebem da sua dimensão, mesmo aqueles que se deslocam propositadamente para a frequentar. Creio que sabem que não estão num local qualquer, mas penso que só mais tarde nas suas vidas se consciencializarão sobre a Escola que muitos fizeram para Ihes dar.

Na capa revejo o Da/UAL, que nos transporta para as linhas do 'Habitar, pensar, investigar, fazer'. O layout EN/PT está bem perspetivado e dá uma boa leitura do texto original, caso os leitores estrangeiros o queiram fazer.

Em termos gráficos, a coluna centro-direita (sem segundas leituras) nos primeiros (e nos últimos) textos, que balizam as entrevistas as duas colunas, vão muito bem. A justificação do texto apenas à esquerda é propiciadora de uma leitura poética, pois partimos de um local e terminamos, linha a linha, um pouco em parte incerta. Como um desenho que, aos primeiros traços, não denuncia o rigor e a pronúncia que pode ter.

Para mim foi um privilégio poder fazer esta leitura antes de existir como livro, propriamente dito. Como se guardasse um segredo em forma de objeto, a que só eu tinha acesso, e que agora é um segredo público, acessível a todos.

RAMALHETE, F.; LOPES, J. C - Fazer uma escola. Da/UAL = To build a school. Da/UAL. Lisboa: Caleidoscópio, 2019, 265 pp. 